\title{
INTRODUCTION: \\ Revisiting The Public and Its Problems
}

\section{Kathleen Knight-Abowitz}

The 2013 Past President's Panel at the Dewey Society annual meeting invited scholars to revisit the classic political text, The Public and Its Problems (1927). Four exceptional papers were presented at the session and are now gathered here to gain the wider audience they deserve.

Dewey's most comprehensive work of political theory and democratic politics, The Public and Its Problems was a response to the deeply embedded skepticism about participatory democracy and public life expressed by democratic realists of the era, most famously, Walter Lippmann in his The Phantom Public (1925). In response to Lippmann, Dewey offered a thorough analysis of early 20 th century democracy and some of his best thinking on both the challenges of, and hopes for, public life in democratic societies. The book remains a key text for pragmatists, particularly those working in education, as the challenges and threats to the ideals of democracy in education-as they relate to curriculum, pedagogy, policy, and politics, for example-abound today as never before. Indeed, we live in an era in which at times it seems the language of public ideals, public purposes, and public education itself seems naïve and hopelessly outdated. It thus seemed an appropriate time for educators to revisit this key text in Dewey's corpus, one of his most important statements on democratic ideals, processes, and problems.

Each of these articles takes up the challenges of transactional communication in a diverse, pluralistic, mediated and stubbornly unequal society. Each explores a relevant historical and contextual arc, analyzing connections between past and present contexts as these scholars model pragmatist inquiry that is nonfoundational, historicist, and connected to cultural realities. Finally, each piece questions what it means to develop communicative, reflective, deliberative publics that can solve shared problems effectively without relying solely on so-called experts, and without the violence that can take many literal and symbolic forms in the world today. As Amy Shuffelton summarizes this theme, which resounds across the articles, the role of the official expert in educational policy-making must be brought into proper perspective to make way for reflective inquiry and social intelligence. She writes, "The knowledge a democracy needs is a social possession, which arises through inquiry and communication around problems perceived to be relevant to the collective. Furthermore, as regards the knowledge 
that ought to inform public policy, technical expertise needs to be connected with practical reason." The role of the official, the role of the teacher, the role of the parent, and the role of the curriculum are all subject to critical analysis in this collection of articles.

Stefano Oliverio, in "The Democratic Public To Be Brought into Existence and Education as Secularization," traces the historical development of dominant Christian discourses of community and officialdom in an effort to understand the meaning of an official in a democratic context, which celebrates the citizen as a participant in governance. Oliverio begins his analysis with a revealing line by Dewey: "since the public forms a state only by and through officials and their acts, and since holding official position does not work a miracle of transubstantiation, there is nothing perplexing nor even discouraging in the spectacle of the stupidities and errors of political behaviour." Throughout the pre-modern eras, priests and monarchs ruled by virtue of religious and magical powers, but in the era of democratic politics, the role of officials must be transformed to gain authority to govern through different means. As Oliverio explains, "If officials, unlike clerics, do not work a miracle of transubstantiation to have the power of their office, what are officials in a democratic society of Deweyan imagination? Quite simply, [they are made] through the transactional ideal of communication." Replacing the certainty of the metaphysical world of knowledge, argues Oliverio, is "participation through communication ... and with the practical engagement with the conditions of common human experience, in order to manage them."

Next, Leonard Waks, in "Literary Art in the Formation of the Great Community," explores the way literary art selects, abstracts, and creates unifying experiences out of those common human experiences and problems. Art is a form of communication, and as Waks argues, artistic presentation of social investigations can "transform members of the Great Society into a Great Community, breaking through the crust of habits that isolate members as atomic individuals." To show this, Waks goes beyond The Public and Its Problems to reveal Dewey's thinking on the matter in Art as Experience (1934). Art plays a central role in community formation, Waks points out, and to ignore this for a more literal and impersonal view of democratic politics is to ignore Dewey's idea that, as Waks reminds us, "communication is itself an art." Waks demonstrates this argument through careful interpretation of Dewey's aesthetics read against his political theorizing in The Public and Its Problems.

Community formation has proven particularly challenging in the modern era of schooling, and Amy Shuffelton sheds light on the prevailing difficulties through her contribution, "The Chicago Teachers Strike and Its Public." How, one might ask, can functional publics form in response to problems of education at a time of mayor control of urban education, a time when teacher labor is tightly controlled by external mandates and measures? In an era when teacher authority is highly 
diminished, and parental agency translated through a reductive consumerist mentality, the strike offers a bracing example of how inchoate publics might form into more powerful, deliberative spaces, if only for fleeting political moments. Shuffelton contends that "the 2012 Chicago Teachers Strike [is] an instance in which a public, in Dewey's sense, briefly emerged in response to perceived problems that raise precisely the set of questions regarding knowledge and democratic governance that Dewey and Lippman addressed." Shuffelton's analysis shows both the potential power and great difficulty of fostering political community across diverse constituencies, where citizens must negotiate multiple levels of official power and authority in our regularly maligned and badly broken US democratic system.

Finally, Thomas Misco moves us from the theme of teacher as political agent, to teacher as a key figure in building political agency within and among her students, both in the United States and in China. In "Controversial Issue Instruction in Context: A Social Studies Education Response to the Problem of the Public," Misco explores the importance, difficulty, and contextual nature of the teaching of controversial issues. Social studies instruction which ignores these issues misses key opportunities to develop habits of reflective inquiry and social intelligence among young people. As Misco writes, "controversial issues, which are avoided or ignored within non-reflective habits, are the underlying problem for the public, both domestically and abroad. To what extent can or will schools provide the conditions for teachers and students to broach controversial issues and invite them to the method of reflective inquiry?" In his timely article, Misco explores the idea of reflective inquiry as it relates to social studies education in the United States today and to moral education as practiced in China. The ideal Dewey consistently advanced to resolve the problem of the public was conversation, reflective inquiry, and improved "conjoint communicated experience" (1916, p. 87), or democracy. In his analysis of the teaching of controversial issues in Chinese classrooms, Misco finds that "moral education within a communist and authoritarian context stymies discussions about controversial issues within China, though increased attention to reflective thinking in this educational context is becoming more prominent." What is more, Misco observes that Chinese teachers may largely lack the political authority or agency to lead the way in these curricular efforts, an important and disturbing parallel with Shuffelton's analysis of the crucial yet limited role of teachers in the United States in creating publics for education problems and contexts.

It is ironic that in a world where it has never been easier to communicate with another human being-sending a text, posting a message, viewing a loved one thousands of miles away on a computer screen-scholars of democracy and education find the "inchoate public" formation of our time as challenging as did Dewey in his day. The arguments collected in the following set of articles mark the perennial challenges of re-creating democracy, yet they also identify resources and insights that we might even boldly call hopeful, in good Deweyan fashion. 
4 KathleEn Knight-Abowitz

Kathleen Knight-Abowitz is professor and chair of the Department of Educational Leadership at Miami University of Ohio. Email: Knightk2@miamioh.edu 